\title{
Analyzing the Need to Reinstate the NGT Ban with Respect to Meghalaya's Rat-Hole Mines
}

Antony Moses*

\section{Abstract}

On $13^{\text {th }}$ December 2018, 15 miners were trapped in a rat-hole mine in the East Jaintia Hills District of Meghalaya. This incident happened despite the ban imposed and the detailed guidelines laid down by the National Green Tribunal (NGT) in 2014, in response to the South Garo Hills incident. As of date, no concrete legislative measures have been implemented by the State Government of Meghalaya, nor by the respective autonomous District Councils to regulate coalmining. Clothed with the protection conferred by the Sixth Schedule, the State harbors rampant scientific mining practices, and its administration argues that it is a necessity for the economic development of the State. As a result, agriculture has been brought to a standstill and the coal mafia plaguing the State has received an added impetus. Rehabilitation of citizens remains a distant dream and the Sixth Schedule protection afforded to the State, facilitates exploitation instead of protecting the masses. This article will argue strongly for the continuation of the NGT Ban and analyze and counter popular arguments that have been presented for the legalization of coal mining in Meghalaya.

Keywords: Acid-Mine Drainage, B.P Katakey Commission, Mines Act, 1952, Mines and Minerals (Development and Regulation) Act, 1957, Sixth Schedule

\section{Introduction}

Mining disasters are a habitual phenomenon in India 1 . In spite of legislations in place, in the past three years, India has recorded 377

* National University of Advanced Legal Studies, Kochi; mosesantony9@gmail.com 
deaths, out of which 210 were in coal mines ${ }^{2}$. However, the rat-hole mining accident that occurred in the East Jaintia Hills of Meghalaya on the $13^{\text {th }}$ of December, brings to the limelight several pertinent issues. Though the incident can be dismissed as another instance of maladministration and supervisory negligence in mining operations, the reason given by the Government as to why it is perpetuated is unconvincing.

In 2012, the South Garo Hills district of the state witnessed a similar catastrophe ${ }^{3}$, and following the incident, a ban on coal-mining was imposed on the State by the National Green Tribunal (hereinafter NGT ban), in April 2014. However, despite the ban and the heartwrenching precedent, the East Jaintia Hills incident is evidence that the practice continues in Meghalaya.

Rat-hole or Coyote hole ${ }^{4}$ mining is an unscientific and primitive sub-surface mining method wherein coal is mined out manually through tunnels made on the coal seams using small tools and machinery. This practice has denuded the State's water and vegetation of its natural vigour and thereby, it has brought all

1 The Chasnala Mine Disaster (1975). See Editorial, No lessons learnt, THE HINDU (Dec. 27, 2018), https:// www.thehindu.com/ opinion/ editorial/no-lessons-learnt/article25836724.ece; The South Garo Hills Disaster (2012). See Sushanta Talukdar, For days on end, 15 workers trapped in Meghalaya rat-hole coalmine, THE HINDU (July 11, 2012), https://www.thehindu.com/news/national/other-states/for-days-onend-15-workers-trapped-in-meghalaya-rathole-coalmine/ article 3627420.ece; Turamidh Mines Disaster (2016). See Three dead in UCIL's Turamidh mines mishap,THEHINDUSTAN TIMES (May29, 2016), https://www.hindustantimes.com/nation/three-dead-in-ucil-sturamdih -mines-mishap/story-GbkunlI1rFaZOHs3p6iyLL.html.

2 See Shiv Sahay Singh, India records 377 mine deaths in three years, THE HINDU (Jan. 02, 2019), https://www.thehindu.com/ news/ national/ india-records-377-mine-deaths-in-three-years/article25892356.ece.

${ }^{3}$ Talukdar, supra note 2.

${ }^{4}$ Rathole Mining, ONLINE NEVADA ENCYCLOPEDIA,http:// www. onlinenevada.org/articles/rathole-mining.(last visited on May 25, 2019). 
agrarian activities to a standstill in the coalmining districts ${ }^{5}$. As a result, much of Meghalaya's population seems convinced that coalmining is their only means of sustainable livelihood. Moreover, the working conditions in these mines are pathetic. These workers crawl into holes that are no less than two feet high inside pits that are almost four hundred feet deep ${ }^{6}$. There, engulfed by darkness, they are constantly under the threat of being exposed to electricity ${ }^{7}$ or methane gas ${ }^{8}$ or disease ${ }^{9}$. Furthermore, it has been estimated that almost 70,000 child labourers have been employed in these mines ${ }^{10}$. These are some of the gross human right violations that the practice facilitates.

Considering these facts, one would say that the intervention of the Union Government is imminent. Yet, a justification cited by the coal miners is the umbrella protection of the Sixth Schedule of the Constitution (hereinafter Sixth Schedule). By the operation of the Sixth Schedule, all land in Meghalaya is either communal or privately owned ${ }^{11}$. As the BP Katakey Committee Report cites, the State was supposedly excluded from the purview of the Coal Nationalisation Act 1973, owing to its Sixth Schedule status ${ }^{12}$.

5 See Rahul Karmakar, Meghalaya's rat hole traps, THE HINDU (Jan. 12, 2019), https://www.thehindu.com/news/national/other-states/13-feared - dead -in-meghalaya-coal-mine/article25736100.ece.

${ }^{6}$ Meghalaya mine collapse: What it's like to work in a 'rat-hole' mine, BBC NEWS (Jan. 3, 2019), https://www.bbc.com/news/world-asia-india46734451.

7 Sushanta Talukdar, Some sub-channels in rat-hole mine may have collapse, says NRDF, THE HINDU (July 05, 2016), https:/ / www.thehindu.com/ news/national/other-states/some-subchannels-in-rathole-mine-mayhave-collapsed-says-ndrf/article3640408.ece

${ }^{8}$ Id.

9 Talukdar, supra note 8

${ }^{10}$ Karmakar, supra note 8

${ }^{11 K a r m a k a r, ~ s u p r a ~ n o t e ~ 6 ; ~ R a h u l ~ K a r m a k a r, ~ I n ~ M e g h a l a y a ~ f l o u t i n g ~ t h e ~ b a n ~ o n ~}$ mining, THE HINDU (Dec. 23, 2018), https:// www.thehindu.com/ news/national/other-states/in-meghalaya-where-it-took-15-deaths-forthe-reality-of-illegal-mining-to-hit-hard/article25808466.ece.

12 See, CENTRAL POLLUTION CONTROL BOARD, REPORT OF THE COMMITTEE CHAIRED BY FORMER JUSTICE B.P.KATAKEY IN THE 
Therefore, by the operation of the Sixth Schedule, "the landowners are also owners of the minerals below their land 13 ". Thereby, it is argued that all mining laws such as the Mines and Minerals (Development and Regulation) Act 1957 (hereinafter MMDR Act), the Mines Act 1952 and all their related rules do not apply to the State. This further sustains the rat-hole mining practice that is flourishing rampantly in the State.

On July 3rd 2019, the Supreme Court attenuated the NGT ban by declaring the ban will not extend to valid and legal mining, as per the MMDR Act, 1957 and the Mining Concession Rules1960,14after acknowledging the negligence on part of the State's authorities (hereinafter July Order). The author argues that the order is illtimed and poorly enforced, especially since no concrete legislative measures have been previously undertaken by the State Government, nor the autonomous district councils, to regulate coalmining, save the Meghalaya Mines and Minerals Policy of 2012, which is improperly drafted. Nor did they take suitable steps or put in place mechanisms to ensure that the MMDR Act, 1957 and the Mines Act, 1952 are operational in the State. In the light of these transgressions, the order is a daring step.

After careful consideration of the perplexity of the issue, there seems to be no viable solution other than continuation of the NGT ban for the time-being. This article will strongly champion for the continuation of the NGT ban, till the introduction of a Coal Regulatory Authority by the Central Government. In doing so, this article will attempt to trace the background of the rat-hole mining

MATTER OF THE STATE OF MEGHALAYA VS ALL DIMASA STUDENTS UNION HASAODISTRICT COMMITTEE \& ORS 2 (2018), https://cpcb.nic.in/NGT/ Report-NGT- 15.01.2019.pdf. [hereinafter BP KATAKEY COMM'N REPORT].

13 Id.

14 State of Meghalaya v All Dimasa Students Union, Dima Hasao District Committee, Civil Appeal No. 10729 of 2018 (July 3, 2019) [hereinafter July Order]. See SC verdict on coal mining people's victory: Meghalaya CM, THE HINDU (Aug. 15, 2019), https://m.timesofindia.com/ india/ sc-verdict-on-coal-mining-peoples-victory-meghalayacm/amp_articleshow/70689123.cms 
practice in Meghalaya and will examine in detail the elements that fuel the practice in the State. It will attempt to explain the environmental damage sustained by the State by virtue of the practice as well. The article will also counter the popular arguments presented for lifting the NGT ban. In consideration of the principle of sustainable development, measures will be suggested to make coal-mining a sustainable activity in the State and will deal with the problem of rehabilitation of its citizens in detail.

\section{The Practice of Rat-Hole Mining: Historical Perspectives}

The status of Meghalaya's hills as a prosperous coal reserve was established long ago. Small scale mining has been operating in Meghalaya since the $19^{\text {th }}$ Century ${ }^{15}$. The first attempt to study the geology of Meghalaya was carried out by Medlicott, in the South Garo Hills in 186916. However, attempts to mine coal on a commercial scale only started in the 1970 's, ${ }^{17}$ in the Khasi Hills. In course of time, Meghalayan coal was in high demand in the tea estates and brick kilns of Assam and therefore, mining operations in Meghalaya expanded to the East Jaintia Hills and to the Garo

${ }^{15} \mathrm{Id}$. at 2. See Karmakar, supra note 6.

16 GEOLOGICAL SURVEY OF INDIA, MINISTRY OF MINES, BULL. SER. A NO. 45, VOL I: COALFIELDS OF NORTH EASTERN INDIA 29 (2ND ED. 2016),https:// www.gsi.gov.in/ webcenter/ portal/ OCBIS/ page169/page1758?_afrLoop=2077299441968697\&_adf.ctrl-

state=4itznwwon_9\#!\%40\%40\%3F_afrLoop\%3D2077299441968697\%26_ adf.ctrl-state\%3D4itznwwon_13

17 KiranmaySarma, Impact of Coal Mining on Vegetation: A Case Study in Jaintia Hills District of Meghalaya, India 2 (Feb. 03, 2005) (unpublished M.S. dissertation, International Institute for Geo-Information Science and Earth Observation) (on file with India Environment Portal). See Directorate of Mineral Resource, Cottage CoalMining in the State of Meghalaya and its impact on the environment, inENVIRONMENT CONSERVATION AND WASTELAND DEVELOPMENT IN MEGHALAYA (A Gupta \& DC Dhar, eds., 2012). 
Hills ${ }^{18}$. By the end of the 1980s's, rat-hole coal mining was rampant in the State ${ }^{19}$.

As of now, two kinds of rat-hole mining practices are followed in Meghalaya - Side-Cutting and Box-Cutting, ${ }^{20}$ depending on the topography of the location. Side-Cutting rat-hole mining is employed in hilly locations such as the South Garo Hills and involves digging of parallel tunnels along a hill slope, until the miners find the coal seam. Later the coal, along with the sand and gravel, is brought outside the mine, through wheel barrows ${ }^{21}$. The more dangerous of the two methods 22 , Box cutting, involves clearing the surrounding vegetation and then vertical pits of 5 to $100 \mathrm{~m} 2$ are dug into the earth, until a coal seam is hit. ${ }^{23}$ Once a coal seam is hit, horizontal tunnels are made into the seam. The miners are put in a precarious position as the tunnel in most cases is about only three to four feet high due to the thin coal seams ${ }^{24}$.

The coal boom in Meghalaya occurred only in the $19^{\text {th }}$ Century by reason of its topography ${ }^{25}$. The terrain and forest cover of the State and the high sulphuric content ${ }^{26 i n}$ Meghalayan coal make it extremely difficult to exploit ${ }^{27}$. Moreover, coal in the State occurs in

${ }^{18}$ BP KATAKEY COMM'N REPORT, supra note 13, at 2.

19 Id

20 BP KATAKEY COMM'N REPORT, supra note 13, at 2.

21 See KiranmaySarma and Pramod K Yadav, Relentless Mining in Meghalaya, India, 1 CONSERVATION SCIENCE 9 (2013).

22 Karmakar, supra note 12.

23 See OP Singh, Impact of Coal Mining on Water Resources and Environment in Meghalaya 253 (2012), https:// www.researchgate.net/ publication/ 303487611_Impact_of_Coal_Mining_on_Water_Resources_and_Environme nt_in_Meghalaya (last visited May 25 2019); BP KATAKEY COMM'N REPORT, supra note 13, at 4 .

${ }^{24}$ BP KATAKEY COMM'N REPORT, supra note 13, at 4 .

${ }^{25}$ Geological Survey of India, supra note 16.

26 BP KATAKEY COMM'N REPORT, supra note 13 , at 4 . See DIRECTORATE OF MINERAL RESOURCES, GOVERNMENT OF MEGHALAYA, TECHNICAL REPORT OF THE DIRECTORATE OF MINERAL RESOURCES (1985).

${ }^{27} \mathrm{Id}$. 
thin seams ${ }^{28}$ over sub-horizontal and gentle deep sedimentary formations ${ }^{29}$ and therefore, they are small and poorly accessible. Under these circumstances, exploring through drilling becomes virtually impossible ${ }^{30}$ and without systematic mapping efforts, large scale mining operations become challenging. Therefore, in its inception at the Khasi Hills, coal mining was taken up as a cottage industry ${ }^{31}$.In 1973, in line with nationalization efforts throughout the country, the Union wanted coal mining nationalized in Meghalaya. The State Government, however, was able to convince the Union that coal mining in Meghalaya-the rat-hole mining we have previously discussed-was merely a cottage-industry that did not require state regulation ${ }^{32}$. They cited the two-pronged, argument of technical and legal difficulties in instituting large-scale mining, and argued successfully, in an inexplicable non-sequitur, that since large-scale mining was not possible in Meghalaya, it was automatically a cottage-industry.

Soon after its recognition as a cottage industry, the tribes of the State claimed mining as a 'customary right ${ }^{33}$ '. The Sixth Schedule, Paragraph 3(a) in particular, enshrines the concept of communal ownership of land and forests in Meghalaya ${ }^{34}$ and at the outset; a major portion of the land in Meghalaya is governed through

28 PK Guha Roy, Coal Mining in Meghalaya and its impact on environment, 4 EXPOSURE 31-33 (1991).

${ }^{29}$ KiranmaySarma, Coal Mining and its impact on Environment of Nokrek Biosphere Reserve, Meghalaya 7 (2002) (unpublished Ph.D. dissertation, North-Eastern Hill University) (on file with North-Eastern Hill University).

${ }^{30}$ Geological Survey of India, supra note 17, at 1.

31 KiranmaySarma, supra note 30, at 6. See Directorate of Mineral Resource, supra note 17

32 Hope of greening the ravaged land, THE SHILLONG TIMES (April 30, 2014), http://www.theshillongtimes.com/2014/04/30/hope-ofgreening-the-ravaged-land/

33 KiranmaySarma, supra note 17; Directorate of Mineral Resources, supra note 17.

34 See WALTER FERNANDES, MELVILLE PEREIRA \& VIZELENU KHATSO, NAT'L COMM'N FOR WOMEN, CUSTOMARY LAWS IN NORTH EAST INDIA: IMPACT ON WOMEN (2005). 
customary laws ${ }^{35}$. This concrete protection of the Sixth Schedule is responsible for unleashing the horrors of rat-hole mining and environmental degradation in Meghalaya. The demand for Meghalayan coal in the surrounding states and countries also adds fuel to the fire. Meghalaya has its own coal consumption centers in the form of power plants and cement plants. Therefore, it further encourages its locals and mine owners to continue with illegal coal mining in the region ${ }^{36}$.

Thus historically, four factors have contributed to this menacing practice: Firstly, the topography of the State; Secondly, the informal recognition of mining as a cottage industry; Thirdly, its recognition as a customary practice under the Sixth Schedule and Fourthly, the rise in demand for Meghalayan coal in the North Eastern States and neighbouring countries.

\section{Environmental Devastation and Human Right Violations:}

The adverse effects of coal mining are quite well-known ${ }^{37}$. Several NGT orders ${ }^{38}$ from time to time have noted the environmental

35 Id. See MP Bezbaruah, Land Tenure System in North East India: A Constraint for Bank Financing?, 8(3) DIALOGUE (2007).

36 Threat to life arising out of coal mining in South Garo Hills District v State of Meghalaya, Original Application No, 110(THC)/2012, p.9 (dated 04 ${ }^{\text {th }}$ January 2019).

37 KiranmaySarma, Impact of Coal Mining on Vegetation: A Case Study in Jaintia Hills District of Meghalaya, India 2 (Feb. 03, 2005) (unpublished M.S. dissertation, International Institute for Geo-Information Science and Earth Observation) (on file with India Environment Portal). See F.G Bell, S.E.T Bullock, T.F.J. Halbich\& P Lindsey, Environmental Impacts Associated with an abandoned mine in the Witbank Coalfield, South Africa, 45 INT'L JOURNAL OF COAL GEOLOGY 195-216 (2001).

38 State of Meghalaya v. All Dimasa Students Union Dima Hasao Dist. Committee, Original Application No. 73 of 2014 \& Original Application No. 13 of 2014 \& Original Application No. 110 (THC) / 2012 6-9 (Aug. 1 2014, Oct. 7 2014; Nov. 12 2014; Mar. 25, 2015); Threat to Life Arising Out of Coal Mining in South Garo Hills District v State of Meghalaya, Original Application No. 110 (THC)/2012 4 (Aug. 31, 2018; Jan. 04, 2019; April11, 2019). 
damage the State has been subject to from the rat-hole mining practice and the Fundamental Right violations that followed thereafter. The earliest official study into the practice was in September 1997, by the Meghalaya State Pollution Control Board ${ }^{39}$ (hereinafter referred to as the 1997 report). The report titled, "Environmental Impact of Coal Mining in Jaintia Hills District", elucidated the environmental impacts and the ecological imbalances caused by the 100-year old rat-hole mining practice. Recommendations were also provided. ${ }^{0}$ However; it remains unimplemented even after 21years ${ }^{41}$.

The report of the recently constituted BP Katakey Commission noted that the quality of water in the rivers of Meghalaya was not fit for human or animal consumption ${ }^{42}$. For example, the content of sulphate was found to be as high as $100.2 \mathrm{mg} / 1$ in the Kalipai River in Rymbai ${ }^{43}$. The colour of the water in these rivers has also been found to be visibly changed ${ }^{44}$.

ThepivotalreasonforthedegradationofwaterqualityinMeghalayaisfo undtobeAcidMine Drainage (AMD) ${ }^{45}$ from abandoned mines ${ }^{46}$. Acid Mine Drainage is produced when air and water react with pyrite (Iron Sulphide) present in coal to produce sulphuric acid and

39 Threat to life arising out of coal mining in South Garo Hills District v State of Meghalaya, Original Application No, 110(THC)/2012 10 (Jan. 04, 2019) [hereinafter January Order]. See BP KATAKEY COMM'N REPORT, supra note 13, at 39-41.

40 January Order, supra note 40, at 10.

41 Id.

42 BP KATAKEY COMM'N REPORT, supra note 13, at 21.

${ }^{43} \mathrm{Id}$.

${ }^{44}$ Lamsuk Nongtdu\& Dr. Mimi Das Saikia, Effect of Coal Mining in Water Quality of Prang River and LynriangRiver, Jaintia Hills, Meghalaya, India, 5(6) INT'L RESEARCH JOURNAL OF ENGINEERING AND TECHNOLOGY 3179 (2018).

${ }^{45}$ OP Singh, supra note 24, at 255.

46 See A tragedy that was long in the making, THE HINDU (Jan. 25, 2019), https://www.thehindu.com/opinion/lead/a-tragedy-that-was-long-inthe-making/article26082607.ece. 
dissolved iron ${ }^{47}$. Considering the high sulphuric content of Meghalayan coal, 48 and the heavy precipitation that the State receives every year, the permeation of AMD into surrounding lands seems almost inevitable. Consequentially, it affects the fertility of the soil and the aquatic life present in the surrounding water bodies ${ }^{49}$. Furthermore, mined coal and other consolidated and unconsolidated waste generated from the mining process, are usually dumped onto the surrounding un mined areas ${ }^{50}$. This results in the creation of hostile substrata for plant growth and moreover, the revegetation and reclamation ${ }^{51}$ of such land becomes a very difficult process 52 .

Therefore, rat-hole mining necessitates large scale removal of vegetation ${ }^{53}$, water, air and soil pollution at every step. This crude

47 OP Singh, supra note46

48 See MINISTRY OF ENVIRONMENT AND FORESTS, STATE OF ENVIRONMENT REPORT, MEGHALAYA 29 (2005), http:// moef.gov.in/wp-content/uploads/2018/04/SoE-report-ofMeghalaya_0.pdf

${ }^{49}$ Pramod K Yadav, supra note 22. See H Nath, Environmental Impact on coal mining with special reference to water pollution in Jaintia Hills, Meghalaya, in ENVIRONMENT CONSERVATION AND WASTELAND DEVELOPMENT IN MEGHALAYA 22-32 (A Gupta \& DC Dhar, eds., 2012).

${ }^{50}$ BP KATAKEY COMM'N REPORT, supra note 13, at 21.

51 See A.D. BRADSHAW AND M.J. CHADWICK, THE RESTORATION OF LAND.THE ECOLOGY ANDRECLAMATION OF DERELICT AND DEGRADED LAND 363-384 (1ST ED. 1980); KJ Chadwick, Methods ofAssessment of Acid Colliery Spoils as a Medium for Plant Growth, in ECOLOGY AND RECLAMATION OF DEVASTATED LAND 81-91 (R.J Hutnik and G Davis, eds., 1973).

52 KiranmaySarma, supra note 17, at 5. See P.A. Constigan, A.D.Bradshaw and RP Gemmel, The Reclamation of Acidic Colliery Spoils, 21(1) JOURNAL OF APPLIED ECOLOGY 401-409 (1984).

53 Pramod K Yadav, supra note 22, at 6. See T Lyngdoh, Community Dynamics and Edaphic Changes in Relation to Coal Mining in Jaintia Hills, Meghalaya (2011) (unpublished Ph.D. Thesis, North Eastern University) (on file with the North Eastern University). 
practice causes large scale damage to natural systems ${ }^{54}$ and the ecological fragility of the State further worsens the effects of coal mining. Nevertheless, the people of Meghalaya still prefer to mine to their deaths, because their economic sustenance depends on it. Due to the contamination of agricultural lands by the practice 55 , the people of Meghalaya are left with no choice but to risk their lives in the mining process to sustain their families and themselves.During rainy seasons, mining becomes a more dangerous activity. Mine walls become loose due to seepage of water into the soil and in the absence of concrete or wood shoring, the collapse of the mine is inevitable ${ }^{56}$.Moreover, the chances of water from nearby streams to permeate into amine's channel sand sub-channels are extreme. In best cases, the mine becomes slushy which makes navigation within the mine harder ${ }^{57}$. In worst cases, the mine floods. Besides, other threats like exposure to methane gas or to electricity continue to endanger the impoverished miners ${ }^{58}$.

The South Garo Hills and the East Jaintia Hills incidents are only the tip of the iceberg, in terms of human right violation. Children become victims to this morbid practice because their smaller physiques make them ideal to navigate through the narrow tunnels ${ }^{59}$. It has been reported that almost 70,000 children ${ }^{60}$ below the age of 10 have been employed in these mines ${ }^{61}$. Furthermore, thousands of active and abandoned rat-hole mines have been used by murderers in the State as a dump yard for the bodies of their

${ }^{54}$ Pramod K Yadav, supra note 22, at 6. See KiranmaySarma, RK Rai \& SK Barik, Impact of Coal mining on vegetation of Nokrek Biosphere Reserve, Meghalaya, in MINING ENVIRONMENT: PROBLEMS \& REMEDIES 77 - 104 (OP Singh, ed., 2005).

55 OP Singh, supra note 24. See S Gupta Das, B.K.Tiwari\&R.S. Tripathi, Coal Mining in Jaintia Hills, Meghalaya: An Ecological Perspective in JAINTIA HILLS, A MEGHALAYA TRIBE: ITS ENVIRONMENT, LAND AND PEOPLE 121-128 (P.M. Passah and A.S. Sarma, eds., 2002 ).

56 Talukdar, supra note 7.

57 Id.

${ }^{58} \mathrm{Id}$.

${ }^{59}$ Karmarkar, supra note 5

${ }^{60} \mathrm{Id}$

${ }^{61}$ Talukdar, supra note 7 
victims ${ }^{62}$. Many of these victims have been found to be women and children who had fallen prey to human trafficking and sex trade ${ }^{63}$.

It is estimated that more than 60,000 mines are spread across 360 villages in the East Jaintia Hills District alone. The mine owners, after extracting coal from a mine, abandon it and as a result, many children and livestock have accidently fallen to their deaths. ${ }^{64} \mathrm{As}$ only a few would dare to search these hellholes, most of the bodies are left to decompose in these pits, until they are found by accident. In the recent East Jaintia Hills incident, during the Navy's efforts to find the bodies of the miners, an unidentified body was also found within the mine ${ }^{65}$. As mentioned earlier, the water inside these mines is highly acidic and therefore, the decomposition process in these pits is faster. This makes them an ideal dumping site for unidentified bodies.

No active steps have been taken by the administration to check the negative environmental effects. The miners too do not take up any pollution control measures or pre and post-mining safeguards ${ }^{66}$. Most importantly, no authority in Meghalaya till date, has taken up the responsibility of remedying these gross violations of Article 21. Until the NGT ban on coal- mining in Meghalaya in 2014, the seatrocities were unbridled in the State and the issue received only minimal media coverage ${ }^{67}$. The events that unfolded after the South Garo Hills incident, demonstrated the negligence and insubordination of the administration in failing to take concrete measures to curb the practice. It brought to light the truth that, unless radical means are employed to restrain the misuse of power

62 Rahul Karmakar, Meghalaya's coal mines are used for disposing bodies too, THE HINDU (Jan. 21, 2019), https:// www.thehindu.com/ news/ national/other-states/meghalayas-coalmines-are-body-disposal-pitstoo/article26044212.ece

${ }^{63} \mathrm{Id}$

$64 \mathrm{Id}$; Karmakar, supra note 5.

65 Navy Robot located body in Meghalaya mine, THE HINDU (Jan. 18, 2019),https:/ / www.thehindu.com/news/national/body-of-one-of-15 trapped- meghalaya- miners-found-by-naval-divers/article26010931.ece. 66 See BP KATAKEY COMM'N REPORT, supra note 13, at 40.

67 See Karmakar, supra note 5. 
in the State, the East Jaintia Hills incident and the consequences that followed from it therein, would only be one in a long line of disasters that would torment its citizens.

\section{Lacunae in Implementing the NGT Order}

The $\mathrm{CM}^{68}$ of Meghalaya, the Opposition ${ }^{69}$ and the association of coalminers and dealers ${ }^{70}$ have all been in support for legalizing coal mining in Meghalaya. They seek"regulated mining with utmost care and safety of miners and environment, to help the State tide over revenue loss and provide relief to people dependent on coal ${ }^{71}$ ". According to them, the banon mining has affected the 'socio-economic condition' of the people who are dependent on coal and it has resulted in terrible loss to the revenue generation of the State ${ }^{72}$.

However, these arguments hold no water. Though the NGT imposed a ban upon the State of Meghalaya, it was always meant to be an interim measure. The ban continues to be in place only on account of the State's reluctance to take appropriate measures and all initiatives of the NGT have been in vain to secure the State's cooperation in this endeavor. Soon after the ban, on $19^{\text {th }}$ May 2014, the NGT directed the State of Meghalaya to provide for: a mechanism to ensure scientific and regulated mining in the and for the quantum of damages to be paid by the polluters to restore the environment of Meghalaya to normalcy ${ }^{73}$. To this extent, the NGT

${ }^{68}$ Meghalaya CM pushes for regulated coal mining, THE HINDU (Jan. 19, 2019), https://www.thehindu.com/news/national/other-states/ meghalaya-cm-pushes-for-regulated-coalmining/article26030691.ece[hereinafter Meghalaya CM]

${ }^{69}$ Legalise Coal mining in Meghalaya, THE HINDU, Dec. 30, 2018, at 9.

${ }^{70}$ It is a question of livelihood: Owners, THE HINDU (Jan. 7, 2019), https://www.thehindu.com/news/national/other-states/it-is-a-questionof-livelihood-owners/article25934581.ece

${ }^{71}$ Meghalaya CM, supra note69.

${ }_{72} \mathrm{Id}$.

${ }^{73}$ State of Meghalaya v. All Dimasa Students Union Dima Hasao Dist. Committee, Original Application No. 73 of 2014 \& Original Application 
also made orders authorizing the creation of a Committee consisting of government officials and the members of the Pollution Control Board 74 to provide for;

a) Suggestions to carry on proper, scientific, regulated and licensed mining.

b) A Mining Plan for the State of Meghalaya

c) A Health Plan for the State of Meghalaya

d) Conditions of transportation of already mined out coal with specific checks and balances ${ }^{75}$

However, on $1^{\text {st }}$ August 2014 (hereinafter August Order), the Court noted that the Committee failed to submit a report on any of the matters it was supposed to investigate and had delegated it to various departments and sub-committees ${ }^{76}$. Therefore, on witnessing the laxity of the State of Meghalaya to deal with the problem on hand, the Court found it necessary to appoint a Committee that would consist of members who were sufficiently independent from the State's machinery. Therefore, the August order authorized the appointment of a new Committee (hereinafter $2^{\text {nd }}$ Committee) consisting of IAS officers, scientists and professors. 77 The callousness of the State and its coal-barons was observed with respect to implementing the NGT Order in the following matters:

\subsection{Installation of Weigh Bridges or Machines and Check Posts ${ }^{78}$}

The State argued that it could not install weighing machines due to 'limitation of space and geographical conditions of the State ${ }^{79}$.

No. 13 of 2014 \& Original Application No. 110 (THC) / 201214 (Aug. 1 2014) [hereinafter August Order].

${ }_{74} \mathrm{Id}$. at5.

${ }^{75} \mathrm{Id}$. at5.

${ }^{76} \mathrm{Id}$

77 Id at 10

78 State of Meghalaya v. All Dimasa Students Union Dima Hasao Dist. Committee, Original Application No. 73 of 2014 \& Original Application No. 13 of 2014 \& Original Application No. 110 (THC) / 20125 (Oct. 7, 2014) [hereinafter October Order]. 
Through later applications made by several mine owners it was brought to the notice of the NGT that weigh bridges were also not installed by the State ${ }^{80}$.

\subsection{Payment of Royalty by Mine-Owners of Coal Declared or Assessed and its Transportation}

Extracted coal from the then shut down mines was valued at Rs. 3078 crores and the royalty payable to the State was estimated to be around 400 crores $^{81}$. Moreover, since the storage of coal would cause serious environmental damage ${ }^{82}$, both the August ${ }^{83}$ order and the order passed by the NGT on $7^{\text {th }}$ October 2014 (herein after October order) permitted the transportation of already extracted coal to protect the State from economic loss and from irreversible ecological and environmental damage. However, little did the Court know that the State's coal-barons were perverse enough to turn a direction of good faith into a license for unrestricted coalmining.

Both the $2^{\text {nd }}$ Committee and the recently appointed BP Katakey Commission observed that, false declarations had been made by coal-mine owners with respect to their stock. As of January 2019, 24,14,878.63 Mega tonnes (MT) of coal were found to be declared. However, only 23,25,663.54 MT of coal was inventoried. Moreover, the BP Katakey Commission observed the presence of freshly greased Cranes and freshly mined coal on the road side ${ }^{84}$. Both these commissions have expressed their suspicions that royalty to the State was already paid not only on the declared stock but also on the quantity of coal yet to be extracted. Therefore, we may

$79 \mathrm{Id}$

80 State of Meghalaya v. All Dimasa Students Union Dima Hasao Dist. Committee, Original Application No. 73 of 2014 \& Original Application No. 13 of 2014 \& Original Application No. 110 (THC) / 201212 (Mar. 25, 2015) [hereinafter March Order].

$81 \mathrm{Id}$.

82 January Order, supra note 40, at 12.

${ }^{83}$ August Order, supra note 74, at10.

84 January Order, supra note 40, at6. 
conclude that the coal-mine owners of Meghalaya have a malafide intention to mine coal despite the ban.

Furthermore, the Deputy Commissioner of the South Garo Hills himself conceded to the fact that illegal coal mining activities had been carried on in spite of the ban ${ }^{85}$ and the fact that the same continues after the ban, further substantiates the view that the State of Meghalaya is indifferent towards curbing the practice in the State. The coal-barons of the State have displayed audacity in disregarding and perverting the orders of the Tribunal to suit their own needs.

\subsection{Formulation of a Mining Policy}

Throughout the tussle between the NGT and the State of Meghalaya, the quasi-judicial body insisted that the State formulate a mechanism or a policy to ensure scientific and regulated mining in the State ${ }^{86}$. In its October order, the Tribunal also observed that the Government has an obligation' to provide humane working conditions, safety gadgets, proper remuneration and such other facilities... That will not expose them (workers) to work in conditions which are bound to expose them to chronic diseases ${ }^{87}$.

Therefore, in 2012, the Meghalaya Mines and Minerals Regulation Policy was passed by the Meghalayan Government. However, the Policy of 2012 was found to be inadequate. The tribunal observed that the policy did not deal with all aspects of mining 88 . The policy is full of promises and aspirations, yet, not a single provision can be found dealing with safety of mine workers or accountability of mine owners. It also needs to be noted that, after a year of the Tribunal's orders, on 25th March 2015 (here in after March Order) the State Government submitted that it simply lacked manpower and forces to implement its orders and carry on counter insurgency operations ${ }^{89}$. Further more, it submitted that it had attempted to

\footnotetext{
${ }^{85} \mathrm{Id}$ at 10.

${ }^{86}$ August Order, supra note 74, at 14.

87 October Order, supra note 79, at 9.

$88 \mathrm{Id}$.

${ }^{89}$ March Order, supra note 81 , at 6.
} 
obtain an exemption from the Central Government under Para $12 \mathrm{~A}(\mathrm{~b})$ of the Sixth Schedule of the Constitution of India. Paragraph 12 A empowers the President of India to exempt an autonomous district or region from the purview of an Act of Parliament or make such modifications as may be required. By the proposal, it prayed for exemption from the Mines and Minerals Rules and Regulations Act 1957, with respect to reconnaissance, prospecting and mining of coal and from the operation of the Coal Mines Nationalization Act $2013^{90}$. However, The NGT explicitly stated that mining in the State cannot be permitted till the time a mining policy or plan is formulated by the State Government, irrespective of whether the Central Government grants it the exemption ${ }^{91}$.

Therefore, despite the State's loud claims to "regulate coal-mining in its territory with utmost care and safety of miners and environment in mind", it has been reluctant to enforce iron-clad laws ensuring scientific and regulated mining in the State and has continuously excused itself from ensuring the enforcement of the tribunal's orders

\subsection{Expenditure from the Meghalaya Environment Protection and Restoration Fund}

The tribunal in its March Order, in line with the Polluter Pays principle, commanded the State Government to collect an additional $10 \%$ on the market value of the coal, in addition to the royalty payable by the coal miners, for every consignment. The same was decreed to be deposited in the 'Meghalaya Environment Protection and Restoration Fund' (hereinafter MEPRF) which was to be maintained by the State, under the direct control of the Chief Secretary of the State of Meghalaya. On a hearing on 31 August 2018, the NGT found out that a sum of 410 crores was credited to the Account ${ }^{92}$. However, the tribunal in its recent order dated $4^{\text {th }}$ January 2019, discovered that the sum deposited in the MEPRF

\section{${ }^{90} \mathrm{Id}$ at 7.}

${ }^{91} \mathrm{Id}$

92 Threat to Life Arising Out of Coal Mining in South Garo Hills District v State of Meghalaya, Original Application No. 110 (THC)/2012 4 (Aug. 31, 2018). 
fund was also not duly spent for the restoration of the environment ${ }^{93}$. Thus, after bearing witness to the mal administration and indifference of the Government of Meghalaya and to the audacity of the coal-barons of the State in explicitly ignoring the orders of the Tribunal, it seems invidious to argue that the ban on coal-mining must be lifted. In the March Order, the Tribunal explicitly stated that the State of Meghalaya was guilty of non- compliance on the basis of its blatant incompetency and inability to execute and comply with the directions of the tribunal ${ }^{94}$. At no point in time did the NGT handicap the Meghalayan government to enforce its will to secure the "socioeconomic condition" of its people. However, the Meghalayan government remains inactive as it was before the ban. One cannot stop to think that, if not for the ban, and the intervention of the NGT, the State Government would continue to harbor gross human right violations and environmental destruction with zero accountability.

However, thesituationhasnowworsenedbytheattenuationoftheNGT ban.In the light of the State administration's callous track-record, at the least, the Supreme Court could have appointed a committee to ensure the proper administration of "legal coal mining" in Meghalaya. The Apex Court has now given a free-hand to the State to resume this holocaust. Unless strong machinations are introduced by the Central Government to ensure sustainable coal mining in Meghalaya or until the Coal Regulatory Authority Bill, 2013 is enacted, a ban on the State's mining practice seems to be the only solution.

\section{The Sixth Schedule Conundrum}

The Sixth Schedule has been given more credit than it deserves with respect to the problems faced by Meghalaya. Though the Sixth Schedule has not been quoted as a reason to lift the NGT ban, the Schedule has been credited as the legal excuse through which coal-

93 January Order, supra note 40, at 4 .

${ }_{94}$ March Order, supra note 81 , at 6. 
barons in the State validate their fiendishness ${ }^{95}$. The BP Katakey Commission report 96 , states that the State, by virtue of its status under the Sixth Schedule, was excluded from the purview of the Coal Mines Nationalization Act 1973. Moreover, by the operation of the Schedule, it is construed that "the land owners are also the owners of the minerals below their land ${ }^{97 "}$. This is the reasoning that has been adopted by the coalminers themselves to bolster the atrocities that they commit in the State ${ }^{98}$. However, the evidence points to the contrary. On examination of the provisions of the Sixth Schedule, we may arrive at three conclusions; Firstly, Paragraph 9 of the Sixth Schedule clearly mandates the payment of royalty for the extraction of minerals to the respective District Council which granted the lease or license for mining. Therefore, it cannot be said that the land owners are the exclusive owners of the minerals embedded within their land. Secondly, Paragraph 12 of the Sixth Schedule explicitly states that all Acts of Parliament are applicable to the Autonomous districts except on a notification made by the Governor expressly excluding an autonomous district from the purview of such an Act. As of now, no such notification has been made in the State Gazette of Meghalaya and therefore, the Mines and Minerals Development and Regulation Act of 1957 and its provisions, which govern the payment of royalty for mining leases govern Meghalaya as well.Thirdly, the Schedule of the Coal Mines (Nationalisation) Act 1973 explicitly includes 6 collieries in Meghalaya namely Barsora, Cherapunji, Laitryngew, Mawsynram and Thangjinarh. Older people who had worked in these collieries can still recollect the names of the Chief Inspectors of Mines who

95 Chandra Bhushan, Rat-hole coal mining must be discontinued, DOWN TOEARTH (Mar. 04, 2019), https:// www.downtoearth.org.in / blog/mining/-rat-hole-coal-mining-must-be-discontinued--63253.

96 BP KATAKEY COMM'N REPORT, supra note 13, at2.

97 Id. See Pramod K Yadav, supra note 22, at 6.

98 Chandra Bhushan, supra note 97; Patricia Mukhim, A Tragedy that was long in the making, THE HINDU (Jan. 25, 2019), https:// www.thehindu.com/opinion/lead/a-tragedy-that-was-long-in-themaking/article26082607.ece. 
had inspected those mines ${ }^{99}$. Therefore, in the absence of any notification made by the Governor of Meghalaya, the Central Act would operate on these mines and therefore, it would be rather absurd to say that coal mines in Meghalaya were not nationalized.

If this is the situation, then how are crude mining practices carried on in the State? The answer to that question would be two-fold.

Primarily, no mine owner or operator in Meghalaya has been granted a mining license. In the August Order, the Pollution Control Board of Meghalaya has submitted that "none of the mine owners or operators, as on date have been given consent to establish and or operate in the entire State of Meghalaya". ${ }^{100}$ The Pollution Control Board does not possess any records on the production of coal in the State or on the numerous rat-hole mines in the State ${ }^{101}$. Puzzlingly, the State itself admitted the fact that neither the mining leases, nor the Environmental Clearance had been granted to any person. Thus it can be inferred that mining was going on illegally 102 .

Secondly, the collieries in Meghalaya that were nationalized by the Coal Mines (Nationalization) Act 1973 have been long shut ${ }^{103}$. Hence, on paper, no mines operate in the State of Meghalaya. Although the author appreciates the wisdom of the administration of Meghalaya to subvert the existing law, then the administration's claims of "economic loss" due to the ban ${ }^{104}$ or the inclusion of coal as a mineral in their Mines and Minerals policy seems logically absurd. Moreover, in the October Order made by the NGT, the State requested for a variation of the order to allow for the payment of royalty in installments citing the "financial problems" of the

${ }^{99}$ Hope of greening the ravaged land, THE SHILLONG TIMES (Apr. 30, 2014), http://www.theshillongtimes.com/2014/04/30/hope-ofgreening-the-ravaged-land/. [hereinafter Hope of greening the ravaged land]

100 August Order, supra note 74, at 12.

101 January Order, supra note 40, at 4.

102 Id.

103 Hope of greening the ravaged land, supra note 102.

104 Meghalaya CM, supra note 69.

40 
coal-miners ${ }^{105}$. Therefore, we may infer that the State is aware of its unconstitutional activities. Furthermore, the Supreme Court in its July Order is of the same view that the Sixth Schedule does not impede the action of any Central Act in the State of Meghalaya. ${ }^{106}$

The provisions of the Sixth Schedule were designed to provide for a self-contained code to protect the people in the hills from the exploitation of the people in the plains. ${ }^{107}$ It was not meant to be an instrument to provide full immunity to its people from the purview of the Unions power and most importantly, from the purview of other provisions of the Constitution. The Sixth Schedule is not a garb to protect fundamental right violations but rather, its existence in the Constitution is meant to reflect the Directive Principles of State Policy ${ }^{108}$. Paragraph 6 and Paragraph 10(2) of the Schedule are pursuant to Article 46 of the Constitution which provides thattheStateshallpromotewithspecialcaretheeducationalandeconom icinterestsofweaker sections especially the Scheduled Tribes and protect them from social injustice and all forms of exploitation ${ }^{109}$. Also, since the repeal of the Coal Mines (Nationalization) Act of 1973110 , the Centre has lost its most valuable bargaining capacity to ensure the welfare of its citizens in Meghalaya.

\section{Unemployment}

In 2015, the Government of Meghalaya claimed that the ban costed them ₹600 crores in revenue ${ }^{111}$. Though the Government of Meghalaya has no control over its coal mines, it cites coal mining as one of its massive contributors to its economy 112 and thereby, it dared to cite the loss of employment to its citizens as a reason to lift

105 October Order, supra note 79, at 6.

106 July Order, supra note 15, at 102.

107 Id.

108 ARVIND P. DATAR, COMMENTARY ON THE CONSTITUTION OF INDIA 2132 (2nd ed. 2010).

${ }^{109} \mathrm{Id}$.

110 See The Repealing and Amending (Second) Act, First Schedule (2017).

${ }^{111}$ Karmakar, supra note 12.

112 Meghalaya CM, supra note 69. 
the ban ${ }^{113}$. The article has dealt with the massive human and fundamental right violations that rat-hole mining effectuates in the State. However, it needs to be investigated whether the money derived from coal-mining is the primary contributor to the State's economy. Both the State of Environment Report 2005114, prepared by the State's Department of Environment and Forests and the Meghalaya Socio-Economic Review 2003115, released by the State's Directorate of Economics and Statistics, cite agriculture as the main occupation of the people of Meghalaya. The State supplies raw materials such as cotton, jute, ginger, turmeric, paddy and maize to both industries outside and inside the State ${ }^{116}$.

However, due to the rat-hole mining practice, all farmlands in the State have been robbed off their fertility. The Lytein River valley, which used to be a prospective paddy-growing area 15 years ago, is now entirely acidic ${ }^{117}$. Consequently, now, most of its population either relies on coal-mining or limestone mining as means of sustenance ${ }^{118}$. The ecological fragility of the State further makes the situation grave. Frequent flooding and the sand deposits by the rivers on farmlands, further push its citizens to take a plunge into the sehellhol es ${ }^{119}$. Hence, it is not out of choice that the people of Meghalaya have shifted their occupation to coal- mining but rather, out of necessity and depravity. Hence, the employment argument made by the State is entirely preposterous.Even if the same is to be considered, the effects of allowing the practice in the State will be cataclysmic and will result in loss of human life. Therefore, lifting the ban is not a viable solution until the State Legislature of

\section{$113 \mathrm{Id}$}

114 State of Environment Report, supra note 49, at 5.

115 DIRECTORATE OF ECONOMICS AND STATISTICS, MEGHALAYA SOCIO-ECONOMIC REVIEW 26 (2003).

116 Id.

117 See Karmakar, supra note 5

118 Id.

119 Rahul Karmakar, Lack of Jobs, debts push villagers to illegal coal mines, THE HINDU (Jan. 08, 2019), https:// www.thehindu.com/ news/ national/other-states/miners-overlooked-risks-for-higherpay/article25934565.ece. 
Meghalaya brings forth a determinate law to regulatethe same. In the meantime, effective means of rehabilitation must be seriously considered.

\section{Measures Taken}

On the $4^{\text {th }}$ January 2019 the NGT, relying on the Katakey Commission report, found the State of Meghalaya and its authorities guilty of gross negligence. On the basis of the polluter pays principle, the tribunal ordered them to pay one hundred crore rupees, as an interim measure, to the Central Pollution Control Board(CPCB) within two months from the date of the order ${ }^{120}$. However, the July Order has vacated this order and has allowed for the transfer of the said amount to the CPCB from the Meghalaya Environment Protection and Restoration Fund. This amount was proposed to be used to rehabilitate the State's environmental devastation

The Committee was also asked to investigate in to fool proof mechanisms that could be adopted to prevent further transportation of illegally mined coal. Some suggestions made by the NGT in this regard include an electronic manifest system for regulating movement of vehicles and issuance of challans and timely audit of power generation and cement plants in the State of Meghalaya with respect to the acquisition of coal ${ }^{121}$.

The Committee, reiterating the observations made by the 1997 report, has recommended the following to lessen the environmental impact caused by the mining activities:

120 January Order, supra note 40, at 16 . See NGT slaps $\square 100$ cr fine, THE HINDU (Jan. 05, 2019), https:/ / www.thehindu.com/sci-tech/energy-andenvironment/illegal-mining-ngt-slaps-100cr-fine-onmeghalaya/article25914767.ece

121 Threat to life arising out of coal mining in South Garo Hills District v State of Meghalaya, Original Application No, 110(THC)/2012 6 (Apr. 11, 2019). 
a) "To generate social awareness among the public in general and the miners in particular about the adverse environmental impacts and the health hazards associated with such unscientific and unplanned coal mining activities.

b) Preparation of the inventory of the mine owners, areas under mining and rate of land use change to get the firsthand knowledge about the quantum of the efforts required for better management of these activities.

c) ToenforcesuitablelegislationsonthelinesoftheNationalMiner alPolicyimmediatelyfor exploitation of coal in most sustainable manner.

d) To engage expert institution for finding out the most suited technologies for the coal exploitation with appropriate pollution control measures in order to ensure that the environment as a whole is not subjected to furthered gradation.

e) To engage the expert institution for finding out the suitable ways for rehabilitation of the mined land in phase manner so that the scarce land resources can be brought back to productive uses. To look for the alternative transport facilities to control vehicular pollution.

f) To identify the suitable location for the storage of coal for sale with adequate facilities to treat dump run offs.

g) To study the aspect of the presence of trace elements in the surface and ground water because the low $\mathrm{pH}$ values increase the dissolution power of water. Large numbers of trace elements are always associated with the coal which gets dissolved in low $\mathrm{pH}$ waters. These trace elements are serious health hazards even in very low concentrations.

h) To introduce lucrative schemes for a forestation in the most affected areas.

i) To develop the State Mineral Policy with the interaction of Government Agencies, Social Institutions, Local Elders and 
the Miners, keeping in view the specific land ownership system of the State ${ }^{122 "}$.

However, these mechanisms are yet to be considered by the State. The July order has only undone the efforts of the Katakey Commission and of the NGT, since the State will no longer be under the supervision of these entities. Though, the ban is still operational over illegal coal mining, the author submits that the NGT order, in its debilitated form, has no effect. Moreover, legalized coal mining in the State is only a far dream since the mechanisms to enforce the MMDR Act, 1952 or the Mines Act, 1957 have still not been put into place. Therefore, the author opines that the Supreme Court must reconsider its decision with respect to the NGT Ban.

\section{Suggestions}

All these measures and initiatives taken by the NGT and the Katakey Commission are indeed welcome. However, the author submits additional suggestions that may be implemented;

\subsection{A Private-Public Partnership for Coal Mining and the Establishment of a Coal Regulator}

The State's coal reserves amount to a massive 559 million tonnes ${ }^{123}$. Therefore, in line with the principle of sustainable development, scientific exploitation of the State's rich coal seams must be seriously considered. With the repeal of the Coal Mines (Nationalization) Act, ${ }^{124}$ the mining business is now open to private entities as well. Consequently, the possibility of private research and the introduction of advanced technology into the State's mining sector is not far-fetched. However, keeping the Sixth Schedule status of the State in mind, a private-public partnership

122 January Order, supra note 40, at 6. See BP KATAKEY COMM'N REPORT, supra note 13 , at 40.

123 STATE OF ENVIRONMENT REPORT, supra note 49, at 28.

124 See The Repealing and Amending (Second) Act, First Schedule (2017). 
seems the most feasible way to accumulate wealth and exploit the resources of the State in a sustainable manner.

With the introduction of private players into the mining industry, the establishment of a Regulator for Coal Mining becomes a necessity. Such a regulator can also act as an instrument to check the mining practices of the State and elsewhere. Considering the reluctance of the State Government of Meghalaya to enact any effective measures to curb or regulate coal mining, the author opines that setting up an independent Coal Regulator would be the ideal solution.

A bill titled the Coal Regulatory Authority Bill was introduced in the Lok Sabha in 2013 to consider the same. However, the Bill lapsed with the dissolution of the $15^{\text {th }}$ Lok Sabha in 2014125. The Bill empowers the Regulator to mandate the formulation of mining plans and mine closure plans ${ }^{126}$ for any mining establishment and to specify the norms of operational efficiency. ${ }^{127}$ Therefore, such a Regulator will ensure that no more mishaps, as in the present case, will occur and it will be a check against those miners who wish to employ sub-standard practices for mining. But the present Bill does not empower the authority to prescribe norms for mine safety. Therefore, the same must be incorporated into the Bill for the sake of effective regulation of the coal mining industry.

Though, the bill is far from perfect, its implementation is the only possible way to ensure that the environmental degradation and human right violations do not continue in Meghalaya.

\subsection{Revising the Present Rehabilitation Policies}

Bottlenecks at the grassroots level must be first taken care of to ensure that these measures reach the targeted families. For example, The Hindu on $8^{\text {th }}$ January 2019 , reported the case of a father of a victim. The old man could not exempt himself from the

125 Independent Regulator for Coal Sector, PRESS INFORMATION BUREAU \(Apr. 27, 2015), http:// pib.nic.in/ newsite/ Print Release. aspx?relid=119748.

126 See The Coal Regulatory Authority Bill, Section 18 (2013).

$127 \mathrm{Id}$. 
loans taken by his deceased son, unless he could produce a death certificate. Being a resident of the State of Assam, the man had been denied of a death certificate in Assam since his son had died elsewhere and he was denied the same in Meghalaya since his son had been involved in illegal mining 128 . Since most of the coal miners have been migrant laborers ${ }^{129}$, a complete rehaul of the administration's policy with respect to rehabilitation of mining victims is expedient.

\subsection{Placing Limestone on River Beds}

As suggested by Prof. O. P. Singh, locally available limestone, which is available abundant quantities in the State, should be laid down on the river and stream beds to improve the $\mathrm{pH}$ level of water ${ }^{130}$. The same will drastically improve the ecological damage sustained by the State.

\subsection{Appointment of Sufficient Personnel}

One of the most important reasons that can be attributed to the failure of the rescue operations during the East Jaintia and the South Garo Hills incidents, is the lack of personnel in the State. Reportedly ${ }^{131}$, the East Jaintia Hills district has "only 26 armed constables, 31 unarmed constables, 12 sub-inspectors and three inspectors". The State had also earlier cited the same during its submissions in the March Order to the Tribunal ${ }^{132}$. Dearth of competent personnel can indeed by fatal during rescue operations since these coal mines are usually located in the remote corners of the State and therefore, the Central Government and the State

128 Rahul Karmakar, Lack of Jobs, debts push villagers to illegal coal mines, THE HINDU (Jan. 8, 2019), https:// www.thehindu.com/ news/national/other-states/miners-overlooked-risks-for-higherpay/article25934565.ece.

${ }^{129}$ Meghalaya mine collapse, supra note 7.

130 BP KATAKEY COMM'N REPORT, supra note 13, at 2.

131 Rat-hole mining rampant in Meghalaya despite the NGT ban, THE ECONOMIC TIMES (Dec. 25, 2018), https:// economictimes .indiatimes. com/ news/ politics-and-nation/rat-hole-mining- rampant -in-meghalayadespite-ngt-ban/articleshow/67242097.cms

132 March Order, supra note 81 , at 6. 
Government must take suitable measures to ensure the deputation of new officers in the State.

\subsection{Rehabilitation of Abandoned Mines}

The rehabilitation of abandoned mines must be taken into serious consideration. In doing so, emphasis must be given to the plantation of native, multi-purpose species that would serve the two-pronged purpose of facilitating ecological succession and catering to the needs of the native population ${ }^{133}$. In line with the polluter pays principle, the mine owners of the semines must be burdened with such responsibility. As suggested earlier, the establishment of a Coal Regulator will be a godsend in this regard.

\section{Conclusion}

The author, through the course of this paper has countered the several arguments put forth by the State of Meghalaya, holding that the grounds that were used were merely illusory and hold no weight. The author has also explored the counter-points to the implementation of the NGT Order and its lacunae. Finally, the author has delved into the problems posed by the Sixth Schedule and its possible solutions. Nevertheless, the most feasible option to be taken must be the reinstatement of the NGT ban. The author supports this ban as the most pragmatic solution as it protects the rights of the miners in Meghalaya as well as the environment. The author has also included several suggestions to mitigate the lacunae arising from implementing the ban.

133 MINISTRY OF MINES, Proceedings of the workshop on "Remediation of Mined - Out and Abandoned Mines- Status and Strategies" (Dec. 19, 2016),https:// mines.gov.in/ writereaddata/ UploadFile/ proceedings5.pdf. 